\title{
Indoor Environmental Quality (IEQ) in Nigerian Tertiary Institutions: The Effect on Performance of Building Technology Lecturers
}

\author{
Arinzechukwu Victor Okanya1 ${ }^{1}$, Japel Asogwa Onyekachi ${ }^{2}$, Ike Joshua Onyedikachi ${ }^{3}$ \\ 1, Department of Industrial Technical Education, Faculty of Vocational and Technical Education, \\ University of Nigeria, Nsukka. Enugu State, Nigeria. Email: arinze.okanya@unn.edu.ng \\ ${ }^{2}$ Department of Industrial Technical Education, Faculty of Vocational and Technical Education, \\ University of Nigeria, Nsukka. Enugu State, Nigeria. Email: chapeljapel@ gmail.com \\ ${ }^{3}$ Department of Industrial Technical Education, Faculty of Vocational and Technical Education, \\ University of Nigeria, Nsukka. Enugu State, Nigeria. Email: joshua.ike@unn.edu.ng
}

\begin{tabular}{|c|c|}
\hline Arti & Abstract \\
\hline $\begin{array}{l}\text { Article history: } \\
\text { Received:15 November } 2020 \\
\text { Revised: 03 January } 2021 \\
\text { Accepted: 04 January } 2021\end{array}$ & $\begin{array}{l}\text { Purpose: This study aimed to examine the Effect of Indoor Environmental } \\
\text { Quality (IEQ) on the Performance of Building Technology Lecturers in } \\
\text { Nigerian tertiary institutions. } \\
\text { Methodology: Three research questions guided the study in which survey } \\
\text { research design was used. The entire population of the study was } 216 \text {, }\end{array}$ \\
\hline $\begin{array}{l}\text { Keywords: } \\
\text { Indoor Environmental Quality } \\
\text { (IEQ), Indoor Air Quality } \\
\text { (IAQ), Thermal Comfort, } \\
\text { Lighting Comfort, Building } \\
\text { Acoustics, Lecturer's } \\
\text { Performance. }\end{array}$ & $\begin{array}{l}\text { comprising } 84 \text { building technology lecturers and } 132 \text { higher technical } \\
\text { officers from six tertiary institutions in Nigeria. A } 38 \text {-item questionnaire was } \\
\text { used for data collection. The instrument was validated by three experts. } \\
\text { Cronbach's Alpha reliability method was used to determine the internal } \\
\text { consistency of the instrument at a coefficient of } 0.89 \text {. A total of } 216 \text { copies of } \\
\text { the questionnaire were administered and } 210 \text { copies were retrieved, } \\
\text { representing a } 92 \% \text { return rate. The data collected was analyzed using } \\
\text { mean, standard deviation and t-test. }\end{array}$ \\
\hline & $\begin{array}{l}\text { Results: The study found out that there exist } 5 \text { items on how the indoor air } \\
\text { quality (IAQ) affect building technology lecturers' performance in Nigerian }\end{array}$ \\
\hline Research Article & $\begin{array}{l}\text { tertiary institutions, } 5 \text { items on how thermal comfort affect building } \\
\text { technology lecturers' performance in Nigerian tertiary institutions, } 7 \text { items }\end{array}$ \\
\hline $\begin{array}{l}\text { Corresponding Author: } \\
\text { Japel Asogwa Onyekachi }\end{array}$ & $\begin{array}{l}\text { on how building acoustics affect building technology lecturers' performance } \\
\text { in Nigerian tertiary institutions and } 6 \text { items on how ergonomics affects } \\
\text { building technology lecturers'performance in Nigerian tertiary institutions. } \\
\text { The study also found } 6 \text { items on challenges of installing Indoor }\end{array}$ \\
\hline $\begin{array}{l}\text { Email: } \\
\text { chapelja }\end{array}$ & $\begin{array}{l}\text { Environmental Quality (IEQ), facilities and } 10 \text { items on the ways of } \\
\text { providing and improving Indoor Environmental Quality (IEQ), in Nigerian } \\
\text { tertiary institutions. } \\
\text { Practical Implications: Lecturers' role on monitoring and maintenance of } \\
\text { IEQ in offices could be enhanced through appointment of Desk officer in } \\
\text { each faculty of the tertiary institutions. The Desk officer will liaise between } \\
\text { the lecturers and maintenance unit of the institutions on IEQ issues. } \\
\text { Originality/Value: The study concluded that improved indoor environmental } \\
\text { quality has a tremendous impact on lecturer's performance, comfort, } \\
\text { workspace utilization and overall productivity. }\end{array}$ \\
\hline
\end{tabular}

\section{Introduction}

Indoor environmental quality (IEQ) is the condition created in buildings by contextual features like characteristics of building elements, characteristics of the occupant, furniture 
and furnishing and mechanical and electrical conditioning facilities (Frontczak, 2012). It is simply described as the conditions inside the building which include air quality, access to daylight and views, pleasant acoustic conditions, and occupant control over lighting and thermal comfort. It may also include the functional aspects of space, such as whether the layout provides easy access to tools and people when needed and whether there is sufficient space for occupants (Jimoh, 2017). The main purpose of indoor environmental quality (IEQ) standards is to best serve the occupants' interest throughout the design, construction and operation phases of built facilities.

Balancing lecturer's performance and the Indoor Environmental Quality (IEQ) has become a conventional trade-off in sustainable building design for higher institutions. Due to the recognition of the impact of IEQ on the occupants of educational facilities, universities have started taking considerable interest in tracking the performance of their buildings. The Indoor Environmental Quality (IEQ) studies in educational buildings have largely focused on students with limited attention to office workers in post-secondary institutions like universities, especially in developing and underdeveloped countries (Asmara et al., 2014). Academic buildings in universities are supposed to be constructed to create stimulating and adaptable indoor environments with workspaces that support various styles of teaching, learning and research (Okolie, 2011). Lecturers' performance in such buildings is usually affected by the Indoor Environmental Quality (IEQ), which, in turn, is influenced by the characteristics of the users and the building itself (Frontczak et al, 2012).

Building can be referred to as something built with roofs and walls such as houses or factories. Building as defined by Rogets, (2014) is any relatively permanent enclosed structure on a plot of land, having a roof and windows. It could be defined as the art of erecting or constructing a walled structure with roofs for permanent use, such as creation of shelter for man and storage of goods (Taleghani et al., 2013). Jimoh (2017) defined building technology as the application of technology to the design of buildings. Building technology programs in universities and other higher institutions incorporate hands-on experience through labs that may be done on campus or at building sites. Building technology covers the planning for the creation of residential or commercial properties, as well as structures. The inherent utility of academic buildings as enabling facilities and operating resources for academic work has therefore become a maintenance management challenge to stakeholders (Jimoh, 2017). University office workers, such as lecturers of building technology, have varied office use patterns that may influence their IEQ satisfaction and performance. The challenge is in recognition of the fact that building technology lecturers spend a high percentage of time, in allocated offices, on assigned duties. The condition of the indoor environment thus has far-reaching effects on the health, stress level, performance and general well-being of lecturers (Dessouky \& Bayer, 2012). Almeida et al. (2015) stated that indoor environmental quality (IEQ) represents a domain that encompasses diverse sub-domains that affect the human life inside a building. These include indoor air quality (IAQ), lighting, thermal comfort, acoustics, ergonomics, and many related factors. 
Indoor air quality (IAQ), which depends on airborne contaminants, is one of the crucial factors that determine the quality of the indoor environment. Providing adequate air quality for the lecturers is one of the most important functionalities of a building. Lung cancer (due to radon), Legionnaires' disease, carbon monoxide poisoning, allergy, and asthma are among the serious health implications of poor IAQ (Asmara et al., 2014). The "sick building syndrome" resulting from inadequate levels of IAQ significantly affects the health and productivity of lecturers (Al-horr et al., 2016). There are two major approaches to tackle IAQ issues in buildings: one is to increase the ventilation rate of outdoor air into the building, and the other is to minimize or control the sources of air pollution within and outside the building (Persily \& Emmerich, 2012). There are two main sources of lighting in buildings; the natural lighting (also called day lighting) and artificial lighting. Available research has shown that offices, classrooms, and laboratories with high quality of lighting environment improve occupant's performance, satisfaction and comfort. Occupant behaviour plays an important yet complicated role in quality luminous environments. Nicol et al. (2006) explored how lighting conditions relate to occupant's satisfaction, accounting for the roles of daylight and blinds. They found that occupants did not significantly adjust lighting levels in response to exterior conditions and occupants with access to daylight were slightly more satisfied than those without access to daylight were. Nicol et al. (2006) also found that occupants tend to prefer bright environments of about 100 foot-candles. In another experiment by Newsham et al. (2009), subjects showed improved mood when provided greater controls of lighting conditions. Asmara et al. (2014) suggested that IEQ could also be enhanced by improving the thermal comfort of buildings.

Thermal comfort refers to a condition that is governed by many environmental and human factors. The environmental factors include air temperature, air velocity, humidity, radiant temperature, and relative humidity, while the major human factors are clothing and metabolic heat. Other human factors include physical health, mental condition, availability of food and drink, and acclimatization. Djongyang et al. (2010) stated that this condition is mostly subjective, which cannot be directly quantified. It has been established that the thermal comfort level is acceptable if at least $80 \%$ of the occupants feel comfortable with it (Taleghani et al., 2013). Building acoustics deals with controlling the quality of sound inside a building. It deals with the sound propagation within the building, room and between rooms (through walls, doors, and floors), respectively. Al-horr et al. (2016) also noted that room acoustics focuses mainly on the sound quality (e.g., easy communication and high level of intelligibility in office spaces), and the reduction/minimization of "unsolicited" sound (e.g., the noise in a room should not be a nuisance to other rooms). The acoustic comfort in a building has a crucial impact on the health, well-being, communication, and productivity of the occupants. The acoustic comfort can be affected by factors, such as the geometry and volume of a space, generation of sound within or outside the space, airborne noise transmission, impact noise, and the acoustic characteristics (absorption, transmission, and reflection of sound) of the interior surfaces. The measuring unit of sound intensity is decibels $(\mathrm{dB})$, and of sound pitch is hertz $(\mathrm{Hz})$ while the comfortable range of sound for humans is typically 20-20,000 Hz (Taleghani et al, 2013). 
Ergonomics deals with the design of objects, systems, and environment, in a manner that ensures human comfort. In fact, ergonomics encompasses all components of IEQ, simply because the prime objective of IEQ is human health and comfort. It covers diverse disciplines such as anatomy, physiology, psychology, and design. Edmonds, (2016) listed some factors that affect the workplace ergonomics, which includes: tasks, tools, equipment, area and space, environment, and organizational pattern. An indoor ergonomist should be specialized in the interrelationship between the human mind and body and the various aspects of a building such as architecture, interior design, building services, structure, materials, and microclimate (Ushada et al, 2017). In general, environmental ergonomics deals with the interaction between people and their physical environment with particular importance on thermal comfort, lighting, and noise. Similar to ergonomics in a residential environment, ergonomics in offices and workplace is also a scientific discipline and a topic of research (Khalid et al, 2018). One of the major purposes of this study is to ascertain how IEQ in tertiary institutions staff offices and other workplaces has a crucial role on the lecturer's performance.

Lecturer's performance is the ability of lecturers to carry out and execute their duties. It is also the degree to which lecturers accomplishes their task (Tong et al., 2017). Research works by Best and Purdey (2012) have established positive correlations between IEQ and comfort levels of users for enhancing well-being, health, safety and performance. A workplace with high IEQ improves the staff health and mood, thereby increasing their performance. Good indoor environmental quality such as access to views, comfortable temperatures, comfortable lighting, good acoustics, and ergonomic design, etc, supports the lecturers' ability to do a good job (Asmara et al., 2014). On the other hand, compromised IEQ hinders their ability to work. It makes good business sense, then, to keep the lecturers happy, healthy, and productive. This, in turn, creates more and higher quality output for teaching and learning in the high institutions of learning. Therefore, IEQ should be given specific focus while designing new buildings as well as in building retrofit plans. Enhanced Indoor environmental quality can improve the quality of life of the occupants; increase the lecturer's performance and the resale value of the building.

The IEQ quality in many tertiary institutions is poor (Iwaro, 2013). The poor work environment resulting from infrastructural decay in many Nigeria's tertiary institutions has been a subject of concern amongst stakeholders in the education sector. Kolokotsa and Santamouris (2015) showed that many tertiary institutions are riddled with dilapidated infrastructures, abandoned projects, poorly maintained offices, laboratories and workshops. Similarly, Persily and Emmerich, (2012) pointed out that there is a general neglect of the importance of IEQ across the tertiary institutions, thus IEQ facilities are not incorporated at the design and construction stages of many building projects in the tertiary institutions. Iwaro (2013) noted that most tertiary institutions which had a few IEQ facilities lost them due to neglect and poor maintenance culture. The IEQ quality in many tertiary institutions is poor due to lack of proper funding to maintain and upgrade infrastructures. Also, the carelessness of most staff while using the offices, laboratories and workshops contribute to poor IEQ 
facilities in the tertiary institutions. Building technology as a course of study aims at providing a fundamental understanding of the physics related to buildings and to propose an overview of the various issues that have to be adequately combined to offer the occupants a physical, functional and psychological well-being (Okoro, 2012). Building technology programs incorporate hands-on experience through labs that may be done on campus or at a building site.

However, studies by Kim et al. (2018) shows that due to poor IEQ of most building technology laboratories, workshops and offices, both staff and student find it hard to carry out effective teaching and learning. In a study conducted by Iwaro (2013), staff and students experienced symptoms like coughing, throat irritation, tiredness, headache and increased wheezing while receiving lectures in labs and workshops. Poor indoor environmental quality of classrooms, laboratories, workshops and offices for lecturers and other staff of the tertiary institutions, could cause health related problems or even lawsuits that are associated with poor indoor air quality, inadequate lighting, thermal discomfort and ergonomic-related occupational injuries. These are collectively described as the Sick Building Syndrome (SBS). Office buildings for lecturers constitute an integral part of the infrastructural facilities required for academic work in universities. Jimoh (2017) stated that major parameters of IEQ affecting health and comfort like thermal and visual qualities have not been included in Minimum Benchmark for Academic Standards (BMAS) by the National Universities Commission (NUC). Jimoh, also noted that the Needs Assessment exercise undertaken in universities failed to consider IEQ as an essential factor for improved staff performance and satisfaction.

Building technology Lecturers spend the majority of their time in their offices carrying out research and preparing lecture notes and other academic presentations; not surprisingly, studies have shown an increase in staff performance when improvements are made to a space's IEQ (Kim et al., 2018). Consequently, poor laboratory and office workspaces in many Nigerian tertiary institutions cannot adequately support the space and comfort requirements of the increasingly collaborative and highly information-based knowledge workforce of the $21^{\text {st }}$ century. According to Jimoh, (2017), Environmental Protection Agency (EPA) exists in Nigeria but the functions covered relate more with external environment of buildings than the indoor. Maintenance of offices of lecturers for functional comfort, satisfaction, good health, and performance remains an evolving challenge to be addressed by maintenance and facilities managers in the Nigerian tertiary institutions.

Hence, there is need to ascertain ways of providing or improving IEQ of buildings in Nigerian tertiary institutions in order to effectively enhance the performance of building technology lecturers. There is also a need to ascertain the challenges of installing IEQ and the possible solutions to curb these challenges. These and other issues form the basis for this study. 


\section{Methodology and Procedures}

The study adopted the survey research design. Nworgu (2006) stated that a survey research design typically employs interview and questionnaire to determine the opinions, preferences, attitudes and perceptions of peoples about issues. The study therefore adopted this design as it sought to measure the perceptions of high institution staff on the impact of Indoor Environmental Quality (IEQ) on building technology lecturer's performance in Nigerian tertiary institutions. The study was carried out in six tertiary institutions in Nigeria. They include the University of Nigeria, Nsukka (UNN), the Federal University of Technology Owerri (FUTO), Michael Okpara University Umudike, Nnamdi Azikiwe University (NAU), the Institute of Management and Technology (IMT) and the Enugu State College of Technical Education. These tertiary institutions were chosen because they are the educational nerve centres of the South East-Nigeria, which has lots of staff and also have enough, laboratories, workshops, classrooms, offices and other infrastructures where this research was carried out. The population for this study is 216 , which comprised 84 building technology lecturers and 134 higher technical officers from the six tertiary institutions. The entire population was used as sample for the study due to the manageable size of the population.

A structured questionnaire was used as an instrument for data collection. The items used a 5point Likert scale of strongly agreed, agreed, undecided, disagreed and highly disagreed, which were assigned numerical values of 5, 4, 3, 2, and 1 respectively. The instrument was subjected to face and content validation by one lecturer from the Department of Industrial Technical Education, UNN and one lecturer from the Department of Building Technology, in FUTO and NAU respectively. This was done to attest the appropriateness of the instrument in measuring what it is intended to measure. The instrument was trial tested on 10 lecturers from Idah Polytechnic in Kogi State. This yielded a reliability co-efficiency of 0.89 using the Cronbach's Alpha formula. Two hundred and sixteen (216) copies of the questionnaires were distributed to the respondents from the six tertiary institutions in the study. From the total distributed questionnaires, 210 copies of the questionnaires were returned yielding a $92 \%$ return rate. The data were collected by administering the questionnaire directly on the respondents by the researchers and two research assistants. The data collected from this study were analyzed using mean and standard deviation in answering the research questions and ttest to test the hypotheses at a probability level of 0.05 level of significance. Any item with a mean value of 3.50 and above was regarded as agreed, while any item with a mean below 3.50 was regarded as not agreed.

Table A; Population Distribution of the Respondents from the six Tertiary Institutions

\begin{tabular}{|c|l|c|c|c|c|}
\hline S/N & \multicolumn{1}{|c|}{ Tertiary Institution } & $\begin{array}{c}\text { Building } \\
\text { Technology } \\
\text { Lecturers }\end{array}$ & $\begin{array}{c}\text { Higher } \\
\text { Technical } \\
\text { Officers }\end{array}$ & Male & Female \\
\hline 1 & University of Nigeria, Nsukka (UNN) & 12 & 29 & 27 & 14 \\
\hline 2 & $\begin{array}{l}\text { Federal University of Technology Owerri } \\
\text { (FUTO) }\end{array}$ & 18 & 22 & 29 & 11 \\
\hline 3 & NnamdiAzikiwe University (NAU) & 14 & 27 & 30 & 11 \\
\hline 4 & Michael Okpara University Umudike, Abia & 10 & 26 & 27 & 9 \\
\hline
\end{tabular}




\begin{tabular}{|c|c|c|c|c|c|}
\hline & State. & & & & \\
\hline 5 & Enugu State College of Education, Technical & 13 & 16 & 25 & 4 \\
\hline 6 & $\begin{array}{l}\text { Institute of Management \& Technology } \\
\text { Enugu(IMT) }\end{array}$ & 17 & 12 & 20 & 9 \\
\hline & Total & 84 & 132 & 158 & 58 \\
\hline
\end{tabular}

Source: Authors

\section{Results and Discussion}

\section{Research Question 1}

How does Indoor Environmental Quality (IEQ), affect the performance of building technology lecturers in Nigerian tertiary institutions?

Table 1.Mean and Standard Deviation of Respondents on how Indoor Environmental Quality

(IEQ), affect the performance of building technology lecturers in Nigerian tertiary institutions?



Cluster B; How thermal comfort affects building technology lecturer's performance in Nigerian tertiary institutions.

\begin{tabular}{|c|c|c|c|c|}
\hline $\mathrm{S} / \mathrm{N}$ & Item Description & $\mathbf{X}$ & SD & Remark \\
\hline 6 & $\begin{array}{l}\text { Lectures' comfort and performance improves when offices and } \\
\text { buildings are well equipped with cooling and heating facilities } \\
\text { such as air conditioners, water heater etc. }\end{array}$ & 4.51 & 0.55 & Agreed \\
\hline 7 & $\begin{array}{l}\text { Mold and other air borne contaminates develop when there is } \\
\text { too much moisture. This causes a great deal of uneasiness and } \\
\text { discomfort amongst staff. }\end{array}$ & 2.57 & 0.55 & $\begin{array}{l}\text { Disagree } \\
\mathrm{d}\end{array}$ \\
\hline 8 & $\begin{array}{l}\text { Extreme temperatures such as low or high temperatures in } \\
\text { offices and buildings can have a disturbing effect on the body of }\end{array}$ & 4.55 & 0.66 & Agreed \\
\hline
\end{tabular}




\begin{tabular}{|c|c|c|c|c|}
\hline & $\begin{array}{l}\text { occupants thereby causing lack of concentration to academic and } \\
\text { office duties. }\end{array}$ & & & \\
\hline 9 & $\begin{array}{l}\text { Routine maintenance of heating, ventilation and air conditioning } \\
\text { (HVAC) systems makes the offices, laboratories and classrooms } \\
\text { more comfortable to use. }\end{array}$ & 4.14 & 0.51 & Agreed \\
\hline 10 & $\begin{array}{l}\text { Inappropriate high temperatures lead to poor satisfaction which } \\
\text { has adverse impact on the mood, performance, motivation and } \\
\text { concentration of the staff. }\end{array}$ & 4.44 & 0.65 & Agreed \\
\hline & Grand mean & 4.34 & & \\
\hline \multicolumn{5}{|c|}{$\begin{array}{l}\text { Cluster C: How building acoustics affect building technology lecturer's performance in Nigerian } \\
\text { tertiary institutions. }\end{array}$} \\
\hline $\mathrm{S} / \mathrm{N}$ & Item Description & $\mathbf{X}$ & SD & Remark \\
\hline 11 & $\begin{array}{l}\text { Noise pollution from alternative power supplies such as heavy } \\
\text { duty generator sets which produce a huge amount of sound } \\
\text { energy can be a discomfort for the staff and can lead to loss of } \\
\text { hearing. }\end{array}$ & 3.75 & 0.69 & Agreed \\
\hline 12 & $\begin{array}{l}\text { Lecturers find it difficult to deliver their lectures to their } \\
\text { students when the classrooms, workshops and laboratories are } \\
\text { not properly fitted with acoustic materials(eg. fibreglass } \\
\text { insulation, drop-ceiling tiles and polyester panels) }\end{array}$ & 3.73 & 0.71 & Agreed \\
\hline 13 & $\begin{array}{l}\text { Lecturers with poor or no acoustic facilities in their offices, } \\
\text { laboratories/workshop finds it difficult to concentrate on their } \\
\text { academic research, and experiments. }\end{array}$ & 4.68 & 0.70 & Agreed \\
\hline 14 & $\begin{array}{l}\text { Poorly built walls and ceilings in offices and classrooms can } \\
\text { provide little or no obstruction to the transmission of noise from } \\
\text { one room to another thereby reducing the concentration level of } \\
\text { the occupants. }\end{array}$ & 3.99 & 0.69 & Agreed \\
\hline 15 & $\begin{array}{l}\text { Quietness or low noise is one basic requirement for a satisfying } \\
\text { office environment. }\end{array}$ & 4.53 & 0.68 & Agreed \\
\hline 16 & $\begin{array}{l}\text { Various office noises such as traffic noise, conversation noise, } \\
\text { machine noise and human activity noise can cause annoyance, } \\
\text { and dissatisfaction with work environment among the staff. }\end{array}$ & 4.34 & 0.67 & Agreed \\
\hline & Grand mean & 3.34 & & \\
\hline \multicolumn{5}{|c|}{$\begin{array}{l}\text { Cluster D: How ergonomics affects building technology lecturer's performance in Nigerian tertiary } \\
\text { institutions. }\end{array}$} \\
\hline $\mathrm{S} / \mathrm{N}$ & Item Description & $\mathbf{X}$ & SD & Remark \\
\hline 17 & $\begin{array}{l}\text { Poor office layout can lead to limited space for the staff to store } \\
\text { and keep research/educational materials in their offices. }\end{array}$ & 3.96 & 0.60 & Agreed \\
\hline 18 & $\begin{array}{l}\text { Inadequate provision of large classrooms and laboratories } \\
\text { amounts to large number of students sharing limited spaces } \\
\text { during lecture periods and this can be very frustrating to both } \\
\text { staff and students. }\end{array}$ & 4.06 & 0.74 & Agreed \\
\hline 19 & $\begin{array}{l}\text { Poor space allocation to workshops and laboratories can lead to } \\
\text { poor spacing of machines, tools and other laboratory } \\
\text { equipments. }\end{array}$ & 4.63 & 0.67 & Agreed \\
\hline 20 & $\begin{array}{l}\text { Poor spaces in workshops and laboratories, may lead to } \\
\text { increased workshop hazards during practical periods, thus } \\
\text { causing discomfort to staff and students as they struggle to } \\
\text { utilize the limited available space. }\end{array}$ & 4.68 & 0.49 & Agreed \\
\hline 21 & $\begin{array}{l}\text { Lecturers find it difficult to impact skills and knowledge on } \\
\text { students in offices, laboratories and classrooms with limited } \\
\text { spaces or poor space layout. }\end{array}$ & 4.03 & 0.44 & Agreed \\
\hline
\end{tabular}




\begin{tabular}{|l|l|l|l|l|}
\hline 22 & $\begin{array}{l}\text { Lecturers' performances are increased when provided with } \\
\text { spacious offices and classrooms which are well furnished with } \\
\text { state of the art teaching and learning facilities like laptops, Wi- } \\
\text { Fi, printers etc. }\end{array}$ & 0.66 & Agreed \\
\hline Grand mean & $\mathbf{3 . 6 8}$ & & \\
\hline
\end{tabular}

Source: Authors

Table 1 showed 4 clusters on how Indoor Environmental Quality (IEQ) affects the performance of building technology lecturers in Nigerian tertiary institutions. In cluster A, all the 5 items on how the indoor air quality (IAQ) affects building technology lecturers' performance in Nigerian tertiary institutions had their mean values ranged from 3.88 to 4.67 which were above the cut-off point of 3.50. The table also showed that the standard deviations (SD) of the items ranged between 0.55 - 1.09 and which indicated that the responses of the respondents were close to each other and the mean.

Cluster B showed that 4 out of the 5 items on how thermal comfort affect staff performance in Nigerian tertiary institutions had their mean values above the cut-off point of 3.50. The 4 items had their mean values ranged from 4.14 to 4.57 . The table also showed that the standard deviations (SD) of the items ranged between $0.55-0.66$ and which indicated that the responses of the respondents were close to each other and the mean.

Cluster $\mathrm{C}$ showed that all the 6 items on how building acoustics affect building technology lecturers' performance in Nigerian tertiary institutions had their mean values ranged from 3.73 to 4.68 which were above the cut-off point of 3.50. The standard deviation indicates that the responses do not vary widely from the mean. Cluster D showed that all the 6 items on how ergonomics affects building technology lecturers' performance in Nigerian tertiary institutions had their mean values ranged from 3.96 to 4.68 which were above the cut-off point of 3.50. The standard deviation indicates that the responses do not vary widely from the mean.

\section{Research Question 2}

What are the challenges of installing Indoor Environmental Quality (IEQ), in Nigerian tertiary institutions?

Table 2; Mean and Standard Deviation of Respondents on the challenges of installing Indoor Environmental Quality (IEQ), in Nigerian tertiary institutions

\begin{tabular}{lllll}
\hline S/N & Item Description & X & SD & Remark \\
\hline 1 & $\begin{array}{l}\text { Poor or Lack of funding has resulted in the non-installation of IEQ } \\
\text { facilities at tertiary institutions. }\end{array}$ & 3.96 & 0.60 & Agreed \\
2 & $\begin{array}{l}\text { Inflation and Increased material costs have made most contractors to } \\
\text { neglect the installation of IEQ facilities at tertiary institutions. }\end{array}$ & 0.74 & Agreed \\
3 & $\begin{array}{l}\text { Mismanagement of funds and resources by the administrative of } \\
\text { tertiary institutions has crippled installation and maintenance of IEQ } \\
\text { facilities. }\end{array}$ & 0.67 & Agreed \\
\hline $\begin{array}{l}\text { Lack of quality talent and lack of skilled labour makes it difficult for } \\
\text { contractors to effectively install state of the art IEQ in tertiary }\end{array}$ & 0.51 & Agreed
\end{tabular}


institutions.

5 Poor maintenance culture of both staff and the administration of $\begin{array}{llll}3.55 & 0.67 & \text { Agreed }\end{array}$ tertiary institutions have contributed to the dilapidation of IEQ facilities.

6 Nigeria depends heavily on imported building materials, 3.690 .66 Agreed unavailability of these materials pose a threat to effective installation of IEQ facilities at tertiary institutions.

\begin{tabular}{ll}
\hline Grand Mean & 3.88 \\
\hline
\end{tabular}

Table 2 showed that all the 6 items on the challenges of installing Indoor Environmental Quality (IEQ), in Nigerian tertiary institutions had their mean values ranged from 3.55 to 4.68 which were above the cut-off point of 3.50.The table also showed that the standard deviations (SD) of the items ranged between $0.51-0.74$ and which indicated that the responses of the respondents were close to each other and the mean.

\section{Research Question 3}

What are the ways of providing and improving Indoor Environmental Quality (IEQ), in Nigerian tertiary institutions?

Table 3; Mean and Standard Deviation of Respondents on the ways of providing and improving Indoor Environmental Quality (IEQ), which affect the performance of building technology lecturer's in Nigerian tertiary institutions.

\begin{tabular}{|c|c|c|c|c|}
\hline $\mathbf{S} / \mathbf{N}$ & Item Description & $\mathbf{X}$ & SD & Remark \\
\hline 1 & $\begin{array}{l}\text { School administrators should provide adequate funding for the } \\
\text { installation of IEQ facilities with good management. }\end{array}$ & 3.96 & 0.63 & Agreed \\
\hline 2 & $\begin{array}{l}\text { School administrators should always provide input to the design and } \\
\text { installation of IEQ facilities at tertiary institutions }\end{array}$ & 4.06 & 0.71 & Agreed \\
\hline 3 & $\begin{array}{l}\text { Physical activity space in offices, classes and laboratories should be } \\
\text { designed to facilitate instruction free of distractions and "pass- } \\
\text { through traffic patterns. }\end{array}$ & 4.63 & 0.67 & Agreed \\
\hline 4 & $\begin{array}{l}\text { Providing a learning environment with adequate acoustics (sound } \\
\text { baffles) which permits staff and students to safely participate in all } \\
\text { phases of teaching and learning. }\end{array}$ & 4.70 & 0.55 & Agreed \\
\hline 5 & $\begin{array}{l}\text { School offices and buildings should be equipped with proper } \\
\text { flooring and lighting, which should be cleaned and sanitized on a } \\
\text { daily basis. }\end{array}$ & 3.55 & 0.67 & Agreed \\
\hline 6 & $\begin{array}{l}\text { Staff and students should be incorporated in the maintenance process } \\
\text { and schedule of IEQ facilities in offices, laboratories and classes to } \\
\text { ensure proper monitoring and management. }\end{array}$ & 3.69 & 0.66 & Agreed \\
\hline 7 & $\begin{array}{l}\text { Suitable laws should be provided to encourage installation of state of } \\
\text { the art IEQ in all tertiary institutions. }\end{array}$ & 3.66 & 0.60 & Agreed \\
\hline 8 & $\begin{array}{l}\text { Conditioning workspace of lecturer for desirable IEQ should be } \\
\text { made commensurate with lecturer's characteristics. }\end{array}$ & 3.67 & 0.65 & Agreed \\
\hline 9 & $\begin{array}{l}\text { Lecturers should be given roles of ensuring regular maintenance } \\
\text { practice of IEQ in their workspaces for desirable results. }\end{array}$ & 3.68 & 0.64 & Agreed \\
\hline \multirow[t]{2}{*}{10} & $\begin{array}{l}\text { The size and conditioning of lecturers' workspaces should be based } \\
\text { more on functions rather than status. }\end{array}$ & 3.66 & 0.67 & Agreed \\
\hline & Grand Mean & 3.34 & & \\
\hline
\end{tabular}

Source: Authors 
Table 3 showed that all the 10 items on the ways of providing and improving Indoor Environmental Quality (IEQ), in Nigerian tertiary institutions had their mean values ranged from 3.55 to 4.70 which were above the cut-off point of 3.50. The table also showed that the standard deviations (SD) of the items ranged between $0.55-0.70$ and which indicated that the responses of the respondents were close to each other and the mean.

\section{Discussion}

The findings on how the indoor air quality (IAQ) affect building technology lecturer's performance in Nigerian tertiary institutions revealed the following; sick building syndrome, such as headache, lethargy, and mental fatigue amongst staff as a result of poor air quality in offices could reduce their overall performance, poor air quality in offices, laboratories and workshops, reduces occupant health and encourages transmission of contagions among staff, and poor indoor air quality in offices and school buildings can harbour aerosol particulate matter which can trigger allergies amongst staff and endanger their health. The findings are in agreement with the findings of Kolokotsa and Santamouris (2015) in which they posited that poor indoor air quality can encourage biological contaminants to be harboured in curtains, ceilings, carpets, rugs, walls and tiles of the building, which can expose the staff to some health risks. This is also in agreement with Kim et al. (2018) who stated that poor ventilated rooms and offices can hinder the concentration level and productivity output of staff, thereby hindering their overall performance.

The findings on how thermal comfort affects building technology lecturer's performance in Nigerian tertiary institutions revealed the following; inappropriate high temperatures have adverse impact on the mood, performance, motivation and concentration of the staff, extreme temperatures such as low or high temperatures in offices and buildings can cause staff performance to decline drastically and routine maintenance of heating, ventilation and air conditioning (HVAC) systems in school buildings and offices promotes staff performance, work rate, and satisfaction. The findings were in consonance with the assertion of Taleghani et al. (2013) who indicated that more staff are always sick when humidity levels in offices are high. Mold and other air borne contaminants develop when there is too much moisture and can pose a great risk to their health conditions. Persily and Emmerich (2012) supported the findings by stating that the staff comfort and performance improves when their offices and buildings are well equipped with heating, ventilation and air conditioning (HVAC) facilities such as air conditioners, water heater etc.

Also, the findings revealed how building acoustics affect building technology lecturer's performance in Nigerian tertiary institutions. They include various office noises such as traffic noise, conversation noise, machine noise and human activity noise can cause annoyance, and dissatisfaction with work environment among the staff, poorly built walls and ceilings in offices and classrooms can provide little or no obstruction to the transmission of noise from one room to another thereby reducing the concentration level of the occupants and noise pollution from generator sets which serve as alternative power supply to offices often lead to lack of concentration and decreased work rate amongst the staff. The findings were in 
agreement with Jimoh (2017) who stated that noise pollution from alternative power supplies and heavy duty generator sets which produce a huge amount of sound energy can be a discomfort for the staff and can lead to loss of hearing and balance.

Furthermore, the findings revealed how ergonomics affects building technology lecturer's performance in Nigerian tertiary institutions which include; poor office layout can lead to limited space for the staff to store and keep research/educational materials in their offices, inadequate provision of large classrooms and laboratories amounts to large number of students sharing limited spaces during lecture periods and this can be very frustrating to both staff and students and poor space allocation to workshops and laboratories can lead to poor spacing of machines, tools and other laboratory equipments. The findings are in agreement with Kang et al. (2017) who stated that lecturers performances are increased when provided with spacious offices and classrooms which are well furnished with state of the art teaching and learning facilities like laptops, Wi-Fi, printers etc. The study is also in line with Khalid et al, (2018) who posited that poor spaces in workshops and laboratories, may lead to increased workshop hazards during practical periods, thus causing discomfort to staff and students as they struggle to utilize the limited available space.

The findings on the challenges of installing Indoor Environmental Quality (IEQ), in Nigerian tertiary institutions revealed the following; Poor or Lack of funding, mismanagement of funds and resources by the administrative of tertiary institutions and poor maintenance culture amongst staff. This finding is supported by Persily and Emmerich (2012) who posited that lack of good maintenance culture, mismanagement of funds and resources by the administrative of most schools has crippled installation and maintenance of IEQ facilities. Also, the findings of the study on the ways of providing and improving Indoor Environmental Quality (IEQ), in Nigerian tertiary institutions revealed the following; suitable laws should be provided to encourage installation of state of the art IEQ in all tertiary institutions, and conditioning workspace of lecturer for desirable IEQ should be made commensurate with lecturer's characteristics. Almeida et al. (2015) supported this by stating that staff should be given roles of ensuring regular maintenance practice of IEQ in their workspaces and conditioning of staff offices should be based more on functions rather than status of the person.

\section{Conclusion and Suggestion}

Based on the discussion of the study, improved indoor environmental quality has a tremendous impact on building technology lecturer's performance, comfort, workspace utilization and overall productivity. The extent to which office workspaces satisfy the desired comfort of lecturers in carrying out assigned duties is reflected by indoor environmental quality (IEQ). The study shows that the intensity of office workspace utilization by lecturers on core academic functions is also a reflection of their performance. Based on the findings of the study and the discussion it is concluded that Environmental design of office buildings for lecturers by the Physical Planning and Development Unit (PPDU) of tertiary institutions is important for ensuring desired IEQ. Specifications in such design will be required in 
construction, operation and maintenance of office buildings of lecturers in conformity with the comfort requirements. Accurate provision, installation and regular maintenance of IEQ facilities in offices, laboratories, classrooms, workshops and other educational buildings will help to improve staff performance, comfort and productivity in Nigeria's tertiary institutions.

Based on the findings, it is recommended that commensurate attention should be given to lectures' characteristics, workspace characteristics and maintenance practice in environmental design of new buildings, of new offices, classrooms, laboratories and maintenance of the existing stock. Considering the fact that standards and regulations on IEQ have not been installed in Nigeria, findings of this study could be used as baseline data for initiating environmental design and performance evaluation of office workspaces of Nigerian tertiary institutions. Conditioning workspace of lecturer for desirable IEQ should be made commensurate with lecturer's characteristics. The maintenance unit of every Nigerian tertiary institution should ensure that staff workspace characteristics are made to blend with desirable IEQ demands, and also ensure adequate monitoring and evaluation of feedback from lecturers-especially where shortfall occurs between the expected and actual IEQ in workspace.

\section{Conflict of Interest}

The authors have not declared any conflict of interests.

\section{Funding}

The costs of conducting the study and for publishing this article are of the authors'.

\section{References}

Almeida RMSF, de Freitas VP, Delgado JMPQ (2015). School buildings rehabilitationindoor environmental quality and enclosure optimization.School Buildings Rehabilitation. Switzerland AG: Springer Nature. 5-17

Al horr Y, Arif M, Katafygiotou M, Mazroei A, Kaushik A, Elsarrag E. (2016). Impact of indoor environmental quality on occupant well-being and comfort: A review of the literature. International Journal of Sustainable Built Environment. 5(1):1-11

Best, R, Purdey, B. (2012).Assessing occupant comfort in an iconic sustainable education building. Australian Journal of Construction Economics and Building, 12(3), 55-65.

Dessouky, Y, Bayer, M. (2012). A simulation and design of experiments modeling approach to minimize building maintenance costs. Computer and Industrial Engineering, 43(1), 423-436.

Djongyang N, Tchinda R, Njomo D (2010). Thermal comfort: A review paper. Renewable and Sustainable Energy Reviews; 14(9):2626-2640.

Edmonds J. (2016). Overview of human factors engineering. In: Human Factors in the Chemical and Process Industries. Amsterdam, Netherlands: Elsevier B.V., Elsevier Inc.; 153- 167.

Frontczak, M. (2012). Human comfort and self-estimated performance in relation to indoor environmental parameters and building features. (Unpublished PhD Dissertation), Technical University of Denmark. 
Frontczak, M., Schiavon, S., Goins, J., Arens, E., Zhang, H, Wargocki, P. (2012). Qualitative relationships between occupant satisfaction and satisfaction aspects of indoor environmental quality and building design. Indoor Air, 22(2), 119 - 131.

Jimoh Issa Ayodeji (2017). Workspace Utilization, Maintenance Practice and Lecturers' Satisfaction with Indoor Environmental Quality in Selected Nigerian Universities. (Unpublished PhD Dissertation), the University of Lagos, Nigeria.

Khalid H, Kogi K, Helander, M (2018). Ergonomics intervention of workplaces using SEANES ergonomic checkpoints. In: $20^{\text {th }}$ Congress of the International Ergonomics Association (IEA 2018); 1125-1134.

Kim J, Kong M, Hong T, Jeong K, Lee M (2018). Physiological response of building occupants based on their activity and the indoor environmental quality condition changes. Building and Environment; 145:96-103.

Kolokotsa D, Santamouris M. (2015). Review of the indoor environmental quality and energy consumption studies for low income households in Europe. Science of the Total Environment; 536:316-330.

Newsham, G, Brand, J, Donnelly, C, Veitch, J, Aries, M, Charles, K. (2009).Linking indoor environment conditions to job satisfaction: A field study. Building Research and Information, 37(2), 129-147.

Nicol, F., Wilson, M., Chiancarella, C. (2006). Using field measurements of desktop illuminance in European offices to investigate its dependence on outdoor conditions and its effect on occupant satisfaction, productivity and the use of lights and blinds. Energy and Buildings, 38(7), 802-813. OECD.

Nworgu B. G (2006). Educational research: basic issues and methodology. Ibadan: Wisdom publishers.

Okoro E. N (2012). Improving Students' Skill Acquisition through Industrial Technical Education in Tertiary Institutions in Anambra State - Nigerian. Vocational Association Journal 17(1):17-22.

Okolie, K. (2011). Performance Evaluation of Buildings in Educational Institution: a case of Universities in South-East Nigeria. (Ph.D Dissertation), Nelson Mendela Metropolitan University, Port Elizabeth, South Africa.

Persily A. K, Emmerich S. J.(2012). Indoor air quality in sustainable, energy efficient buildings. HVAC \& R Research.18(1-2):4-20

Shexang Kang, Dayi Ou, Cheuk Ming Mak (2017). The Impact of Indoor Environmental Quality on Work Productivity in University Open-Plan Research Offices. Build and Environment; http://dx.doi.org/10.1016/j.buildenv.2017.07.003.

Taleghani M, Tenpierik M, Kurvers S, Van Den Dobbelsteen A. (2013). A Review into Thermal Comfort in Buildings. Renewable and Sustainable Energy Reviews.26:201-215.

Tong Y, Abu Bakar H, Sari KM, Ewon U, Labeni M, Fauzan N (2017). Effect of urban noise to the acoustical performance of the secondary school's learning spaces; a case study in BatuPahat. IOP Conference Series: Materials Science and Engineering; 271(012029):1-8

Ushada M, Suyantohadi A, Khuriyati N, Okayama T (2017). Identification of environmental ergonomics control system for Indonesian SMEs. In: 3rd International Conference on Control, Automation and Robotics; 24-26 April 2017; Nagoya, Japan. pp. 453-456.

Mounir El Asmara, Abbas Chokorb, Issam Srourc. (2014). Are Building Occupants Satisfied with Indoor Environmental Quality of Higher Education Facilities? The International Conference on Technologies and Materials for Renewable Energy, Environment and 
Sustainability, TMREES14(EUMISD) doi: 10.1016/j.egypro.2014.06.093. Science Direct. 1876-6102 (C) Elsevier Ltd.

Iwaro, J. Mwasha, (2013). The Impact of Sustainable Building envelope design on Building sustainability using intergrated performance model. Int, J. Sustainable Built Environ. 2(2), 153-171. 